\title{
EL ESTUDIO DE LAS INTERACCIONES DISCURSIVAS EN CLASES DE QUÍMICA POR MEDIO DE UN ANÁLISIS MULTIDISCIPLINAR
}

Ademir de Jesus Silva Júnior

ajesus@uesb.edu.br

Doctorado en Educación en Ciencias Experimentales

Lugar de realización: Universidad Nacional del Litoral/ Universidade Estadual do Sudoeste da Bahia

Fecha de la defensa: 9 de agosto de 2019

\section{RESUMEN}

Esta investigación presenta una propuesta de análisis multidisciplinario para las interacciones discursivas en las clases de Química. Utilizamos como referenciales para esa herramienta la teoría sociológica de Basil Bernstein, cuyos conceptos permiten relacionar los microcontextos de las interacciones discursivas en el aula con el contexto social más amplio, los tipos de iniciación propuestos por Hugh Mehan así como la noción de enfoque comunicativo de Mortimer y Scott que permite caracterizar los géneros del discurso en clase. Como ilustración del uso de este modelo analizamos episodios de clases de cuatro profesores de química de la Enseñanza Media, siendo dos profesores de escuelas públicas y dos de la red privada, en que el contenido fue Estados Físicos de la Materia y Modelos Atómicos. Para la caracterización pedagógica de los profesores, utilizamos el modelo "centro-periferia" de Sá Earp, donde tres tipos de estructuras son propuestas: "periferia", "centro-periferia" y "centro". El análisis permitió relacionar los conceptos de encuadramiento y de clasificación con los tipos de iniciación y de abordaje comunicativo, e insertar las dimensiones de poder y control. Consideramos que nuestro instrumento analítico para el estudio de las interacciones discursivas representa un lenguaje de descripción externa que permite caracterizar el discurso en sala de clase y contrastar este discurso entre escuelas en que los individuos presentan diferentes perfiles socioeconómicos. Entendemos que nuestra estructura analítica propuesta en esta tesis contribuye de forma original e inédita para investigar como los enunciados y géneros discursivos son modulados por los contextos sociales en clases de Química.

\section{ABSTRACT}

\section{The study of discursive interactions in chemistry classes by means of a multidisciplinary analysis}

By This research presents a proposal of multidisciplinary analysis for the discursive interactions in the Chemistry classes. We use as a reference for this tool the sociological theory of Basil Bernstein, whose 
concepts allow to relate the microcontexts of the discursive interactions in the classroom with the broader social context, the types of initiation proposed by Hugh Mehan as well as the notion of communicative approach of Mortimer and Scott that characterizes the genres of discourse in class. As an illustration of the use of this model, we analyzed class episodes of four middle school chemistry teachers, two professors from public schools and two from the private schools, in which the content was Physical States of Matter and Atomic Models. For the pedagogical characterization of teachers, we use the "center-periphery" model of Sá Earp, where three types of structures are proposed: "periphery", "centerperiphery" and "center". The analysis allowed to relate the concepts of framing and classification with the types of initiation and communicative approach, and to insert the dimensions of power and control. We consider that our analytical instrument for the study of discursive interactions represents a language of external description that allows us to characterize discourse in the classroom and to contrast this discourse between schools in which individuals have different socioeconomic profiles. We understand that our analytical structure proposed in this thesis contributes in an original and unpublished way to investigate how discursive statements and genres are modulated by social contexts in Chemistry classes. 